\title{
Effectiveness of the GAEC standard of cross compliance Prohibition of performing unauthorized land levelling on soil erosion control
}

\author{
Paolo Bazzoffi, ${ }^{1}$ Pier Carlo Tesi ${ }^{2}$ \\ 'CRA-ABP Agricultural Research Council, Agrobiology and Pedology Research Centre, Firenze; \\ ${ }^{2}$ Landscape architect, curator of the plan City of Wine, Firenze, Italy
}

\begin{abstract}
The GAEC standard land levelling under authorization of cross compliance prohibits farmers from levelling land through bulldozing without a specific permission issued by the proper territorial authority. The aim of the standard is to ensure the protection of soil from accelerated erosion that almost always occurs when land is levelled without conservative criteria. Land levelling prior to planting or replanting specialized crops, especially orchards, is indicated by agronomists as essential to the full mechanization of cultivation and harvesting operations and the success of economic investment. Land levelling leads to a deep modification of the hill slopes, so it may produce serious damage to the environment if carried out in the absence of a carefully planned design. In other words, a design that takes the aspects of soil conservation into account, especially for steep hill slopes where the insite and offsite environmental impacts of soil erosion may be more pronounced. With regard to the areas involved, land levelling plays a key role on a national scale, one only needs to think of the vineyards planted on the country's hill slopes, which in 1970 covered an area of 793,000 hectares. Moreover, despite the continued reduction in areas planted with vines, from 1990 to 2002 the area devoted to DOC and DOCG wines increased by about $29 \%$ and the average size of vineyards has also increased. This is a clear sign of the current trend, with the transition from the family model to the industrial model of orchard management, with extensive use of machinery and thus the use of bulldozers for levelling. The authorization topic, on which the standard of compliance is based, is analysed in detail. In summary we can say
\end{abstract}

Correspondence: Paolo Bazzoffi, CRA-ABP Agricultural Research Council, Agrobiology and Pedology Research Centre, p.za M. D’Azeglio 30, 50121 Firenze, Italy. Tel. +39.055.2491228 - Fax: +39.055.241485.

E-mail: paolo.bazzoffi@entecra.it

Key words: soil erosion, land levelling, gaec standard, cross-compliance, territorial governance.

Received for publication: 24 March 2011.

Accepted for publication: 22 April 2011.

(C) Copyright P. Bazzoffi and P.C. Tesi, 2011

Under no circumstances figures can be used without prior written consent of the copyright owner.

Licensee PAGEPress, Italy

Italian Journal of Agronomy 2011; 6(s1):e4

doi:10.4081/ija.2011.6.s1.e4

This work is licensed under a Creative Commons Attribution NonCommercial 3.0 License (CC BY-NC 3.0). that, according to law, the permit required by the GAEC standard is currently mandatory only for those areas subject to the Hydrogeological constraint (Royal decree 30 December 1923 No. 3267) and for parks or other areas for which the regional regulations are more rigorous. Land levelling in other agricultural areas is excluded from the requirement to obtain prior authorization. Owners are only required to submit a DIA (statement of commencement of activity) to the Public Authority. However, permission is granted by law, in the event of lack of ruling by the Authority (implicit consent principle). This GAEC standard assumes that permission (where due) granted by the local authorities responsible for territorial governance is sufficient to avoid the damage that could be caused by land levelling. In other words, the standard does not dictate the agronomic rules to be followed in carrying out land levelling, but refers to already existing local rules and assumes that the authorization is granted on the basis of a detailed Environmental Impact Assessment (EIA). At the present time, only a few local governments take land levelling into consideration in their territorial governance legislation. In general, there is no rule requiring that the application for authorization be accompanied by a project containing the items considered necessary, in the present study, to enable the authorities to express well-pondered judgment. In addition, local territorial rules do not require the execution of land levelling and subsequent approval of the finished work to be carried out under the supervision of a geologist or a pedologist. At present, the GAEC standard is very weak, due to the lack of coordination between the provisions of cross compliance and territorial governance legislation focused on land levelling. It is common practice for the landowner, after obtaining permission, to assign the work to an earthmoving company with no expertise in soil protection and which possibly also has an interest in moving large volumes of earth. This may contribute to an increase in severe environmental damage. Land levelling, undertaken by virtue of a simple DIA and lacking environmental expertise, is very risky and can cause severe damage to soil resources and the landscape. This is particularly true in areas prone to hydrogeological risk or where the soil is thin or fragile in relation to some of its qualities or environmental functions. The results of some researchers on Italian case studies have shown the extent to which land levelling undertaken disregarding the rules of environmental protection can cause serious disturbance to the soil resource, resulting in impressive truncation or burial of the original soil profile, with severe reduction in land capability, ${ }^{1}$ even to the extent of desertification. Results showed that there was a drop in production, especially in excavation areas. Furthermore, changes in the quality of products and a general decay in the vegetative state of plants and water stress were observed. In one case study, land levelling performed before planting a vineyard determined excavation and accumulation thicknesses respectively up to 19 and 16 metres.

${ }^{1}$ Land capability $=$ the potential of land for agriculture and forestry depending on its physical and environmental qualities. The main factor investigated is soil type; but climate, gradient, and aspect are also considered. Present land use is not taken into account. 
In another case study soil erosion after land levelling reached values of over $300 \mathrm{Mg} \mathrm{ha}^{-1}$ (classified as catastrophic erosion). This value is far from the limits of a tolerable erosion of 6-11.2 $\mathrm{Mg} \mathrm{ha}^{-1}$ year-1 currently internationally accepted. The proposals to update the GAEC standard are as follows: i) extension of the land levelling under authorization rule to include also land remodelling (light bulldozing following the removal of an old plantation, to prepare the land for a new plantation); ii) obligation to submit a geological and pedological feasibility study in order to obtain authorization.

\section{Introduction}

\section{Legislation and aim of the study}

GAECs (Standards of Good Agricultural and Environmental Condition) form part of the requirements under cross compliance and apply to anyone receiving payments under the Single Payment Scheme. GAECs set requirements for farmers in respect of soils, as well as maintaining a range of habitat and landscape features which are characteristic of the Italian countryside.

The GAEC standard Prohibition of performing unauthorized land levelling was introduced by the Ministry of Agricultural, Food and Forestry Policies (Mipaaf) decree on Cross compliance up to 2008 (rule 4.4 maintenance of landscape features) with the aim of ensuring a minimum level of habitat maintenance. The following Decree 30125 of December 2009 (after the Health Check) maintained this standard (named standard 1.1) under Rule 1 (measures for protection of the soil) with the aim of ensuring protection of soil from erosion.

In the present work the standard has been evaluated concerning the effectiveness of protecting soil from erosion, by considering the results observed in some study cases in which the land was levelled without adopting the most elementary conservation measures; the current standard, if not supported by effective territorial governance legislation, is not sufficient to avoid the damages caused by land levelling.

Under the environmental aspect, it is illogical to assess the damage caused by soil erosion after levelling only. For this reason also the direct impact of bulldozing on the soil resource was evaluated. This study has been carried out under the project EFFICOND ${ }^{2}$ focused on evaluating the effectiveness of the GAEC standard in force since December 2009.

\section{Synthetic description of the state of the art}

Generally, pedogenetic processes are very slow and require hundreds of thousands of years to form a few centimetres of soil (Kendall and Pimentel, 1994; Stallard, 1995).

Scientific literature defines as acceptable maximum soil erosion rates between 6 and $11.2 \mathrm{Mg} \mathrm{ha}^{-1}$ year-1, depending on whether reference is made to the limits indicated respectively by OECD (2001) or by Natural Resources Conservation Service (NRCS-USDA, 1999). However, with a very slow rate of soil formation, any loss of soil in excess of $1 \mathrm{Mg} \mathrm{ha}^{-1}$ year-1 can be considered to produce irreparable damage over a period of 50-100 years (EEA, 1998). For an exhaustive study on this complex issue, refer to Bazzoffi (2009).

${ }^{2}$ EFFICOND $(E F F=$ Effectiveness of environmental standards, COND $=$ Cross compliance) is a CRA (Agricultural Research Council) project started in 2009 to meet the specific need of NRN (National Rural Network) to monitor and evaluate the effectiveness of environmental protection actions mandated by the CAP to national agricultural policy and implemented by the Regional Rural Development Plans (RDP). The main project objectives are the evaluation of GAEC standards implemented under cross compliance and the development of agri-environmental indicators for nation-wide scenario analysis. The EFFICOND project involves 10 operational units with experimental fields located throughout the country.
Adopting a value of $11.2 \mathrm{Mg} \mathrm{ha}^{-1}$ year-1 as a reference standard and comparing it with the soil losses that occur due to levelling, there is good cause for alarm. One only needs to consider that a layer of only 5 $\mathrm{cm}$ removed by a bulldozer corresponds to an erosion of approximately $800 \mathrm{Mg} \mathrm{ha}^{-1}$ and the layer of soil removed by levelling often arrives at a thickness of several metres (Figure 1).

In Italy's hilly areas, the plantation of new specialized crops (mainly orchards and vineyards) is almost always preceded by levelling of hill slopes. The purpose of these operations, which agronomists consider essential, (Morando, 2001; Panichi et al. 2006), is to achieve economic optimization: with large areas and regular slopes, the execution times of agricultural operations are reduced and machinery performance is improved. The extension of levelled areas has made the morphological discontinuity of hill slopes more evident; the presence of ample uniform inclined plains on hill slopes is common to see in Italy's hilly areas, in contrast with the surrounding natural morphology, which have given rise to a radical change in the landscape. Intervention by bulldozers is not limited merely to the plantingstage. Usually it is repeated in the re-plantation stage of orchards and vineyards to eliminate the old plants and leave as uniform as possible the soil surface, which at the end the plantation life-cycle often shows deep erosion incisions. On steeply sloping hills, where it is impossible to realize a plantation along the maximum slope gradient, the creation of dry stone walls and earth terraces is the only way presently considered valid for creating specialized cultures (particularly viticulture). In both cases (new plantation or re-planting), excavations cause the movement and redistribution along the slopes of enormous quantities of soil, with consequent possible serious damage to the ecosystem. Alteration of the original morphology of vast areas may in itself represent serious damage when it negatively impacts the aesthetic value of the landscape and on biodiversity.

The following two aspects produce the main effects on the soil: in the excavation areas truncation of the soil profile occurs, while in accumulation zones it is buried with consequent sudden modification of pedogenetic dynamics.

In areas where bulldozers remove the soil, deep horizons or even bedrock may come to the surface (Figure 1b). Generally, the characteristics of these materials are unfavourable for plant life. They may strongly limit the depth of the root apparatus, causing water deficiency and are characterized by a reduced content of organic matter and nutrients. The structure of these materials is absent and often massive, the volume of available water is low and biological activity is scarce.

In areas where bulldozers accumulate material, the soil is destructured, compacted by bulldozers but substantially unconsolidated and characterized by lack of pore connectivity and vulnerable to all forms of erosion and mass movements: rill, gully, channel erosion, surface landslides (Figures 2 and 3). In general, just after land levelling, runoff water is not kept under control by an efficient ditch system. The accumulated earth materials very often collapse under concentrated runoff and consequently severe gully erosion occurs. The risk of erosion increases in relation to the increase in length and gradient of the slopes.

In general, levelling takes place in the summer season, to facilitate bulldozer operation. As a result, the bare soil prepared for planting is fully exposed to thunderstorms during the summer-autumn period, characterised by pronounced rainfall erosivity (Bazzoffi and Pellegrini, 1992; Grimm et al., 2001).

In areas where the soil is a limiting factor to land suitability, due to scarce thickness, high erodibility, heterogeneity, or slow pedogenesis, frequent levelling triggers the start or acceleration of hydrogeological instability with irreversible impoverishment of the soil resource (desertification).

\section{Importance of levelling on national territory}

By observing the evolution from 1963 up to the present day, it is pos- 


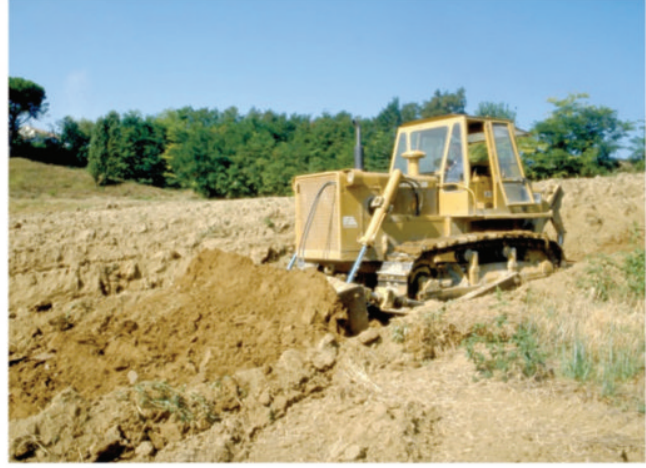

A

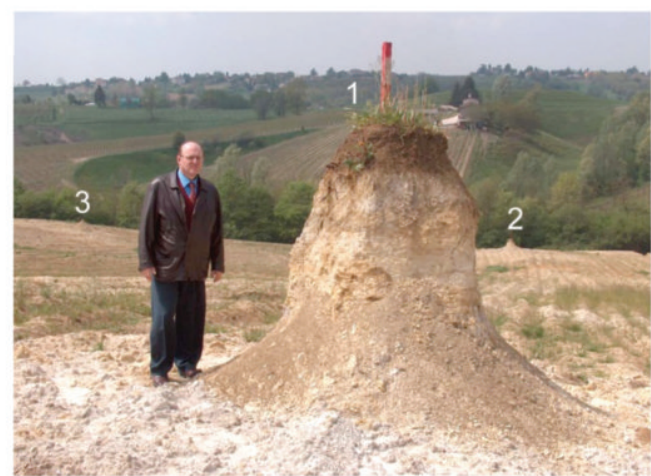

$\mathrm{B}$
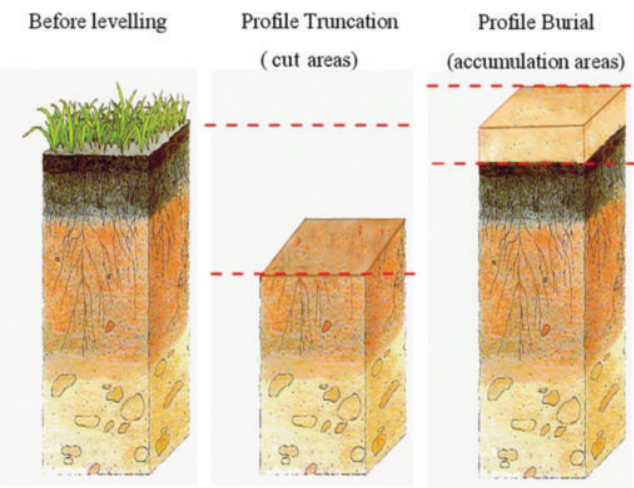

$\mathrm{C}$

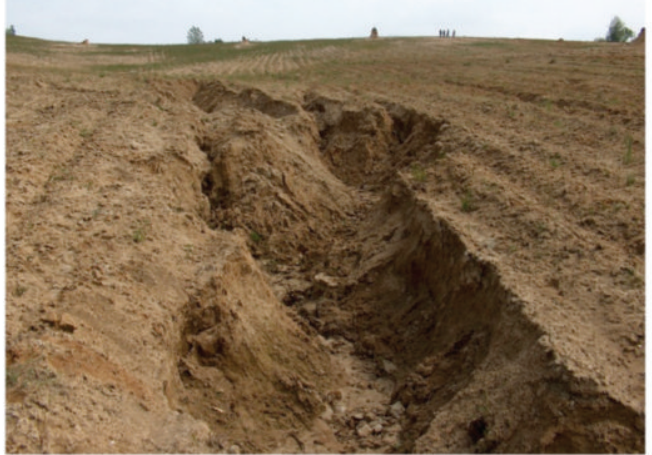

D

Figure 1. A) land levelling before vineyard plantation; B) excavation of over 2 metres of soil, about $34,000 \mathrm{Mg} \mathrm{ha}^{-1}$ of soil removed over a very vast area. Numbers indicate the residues of the original soil left by the bulldozer company to demonstrate to the landowner the work done; $C$ ) sketch view of the effects of land levelling on soil profile; D) gully erosion after land levelling on accumulated earth material.

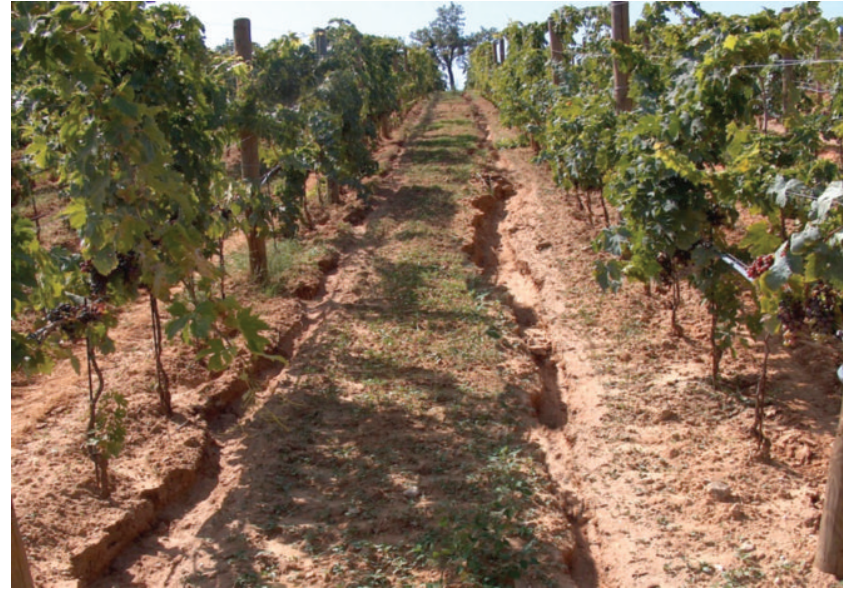

Figure 2. Deep gullies in a vineyard on a levelled hill slope at Ripa Teatina (Chieti). Note the formation of rills in the tractor tracks.

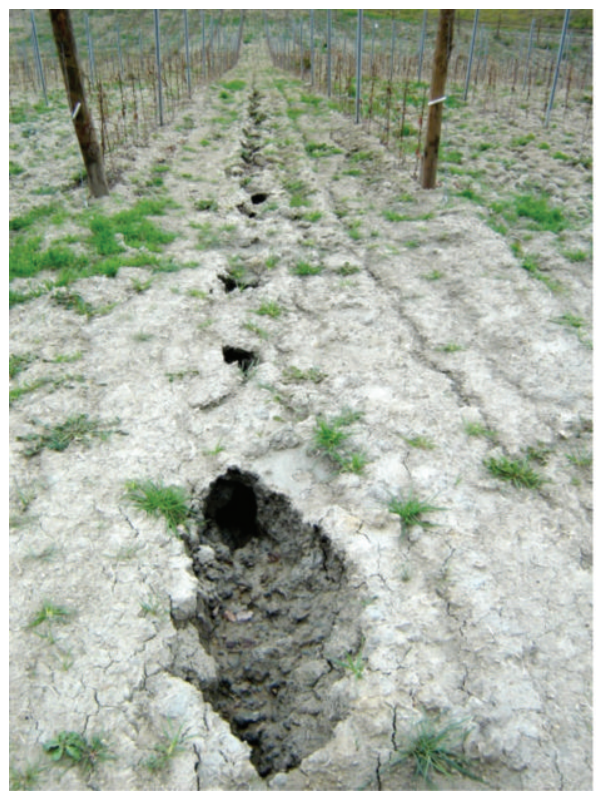

Figure 3. Tunnel erosion in a newly planted levelled vineyard at Artimino (Firenze).

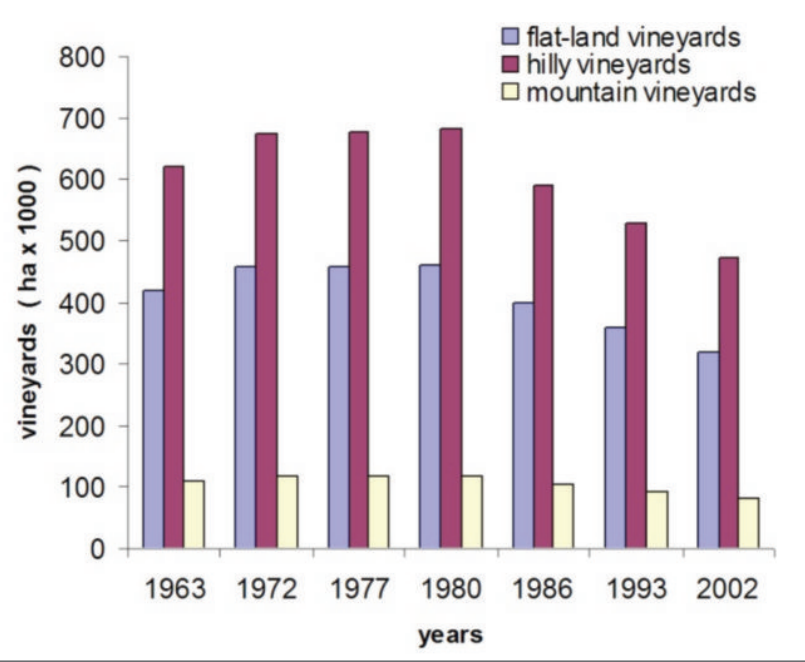

Figure 4. Evolution of the area devoted to vineyards in Italy by altimetric area. 
sible to observe the impact of levelling on the soil in Italy in terms of the extension of land destined for specialized vineyards (Figure 4 and 5), and the prevalence of vineyards in the altimetric area of hills (Figure 6) where, precisely due to the need for integral mechanization of operations, soil levelling takes place before planting. Between the 60 's and the early 80 's, the continuous increase in farm land dedicated to the cultivation of vines reached $9 \%$. Later there was a rapid reduction in vine-growing land (ISTAT, 2001; INEA, 2003), which in 2000 amounted to $60.7 \%$ of the vine-planted area in 1970. Despite this drop, from 1990 to 2002 (Figures 6 and 7) the area devoted to DOC and DOCG vineyards ${ }^{3}$ increased by about $29 \%$ and the average size of vineyard per estate substantially increased. This is a clear sign of the current trend which sees the transition from a family model to an industrial model of vineyard, with widespread use of machinery and consequently bulldozers to level and reshape the land. To the extension of the vine-growing area it is necessary to add the hectares dedicated to other herbaceous and arboreous cultures for which the soil is levelled, but this figure is not easy to determine.

\section{Materials and Methods}

\section{Effects of earth movement - Study sites}

The volume of soil moved following pre-plantation levelling was calculated for three sample viniculture areas located at Cesena, San Gimignano and in three Prosecco production areas in Veneto: Conegliano, Valdobbiadene and Asolo. The morphological change in the hill slopes was assessed by means of a diachronic comparison of Digital Terrain Models (DTM) before and after levelling. The surface heights of the soil before levelling were obtained by photogrammetric restitution applied to stereoscopic aerial photographs. Post-levelling heights were acquired by a high-precision celerimetric survey, using a Leica 1200 geodetic GPS in differential RTK mode.

\section{Study site - Veneto}

The research was conducted on nine vineyards in the Conegliano, Valdobbiadone and Asolo municipalities. A statistical analysis of the heights (Table 1) shows that following levelling, there was a rise in ground level in almost all cases, with the exclusion of vineyard no. 5 . The mean rise for the 9 vineyards considered was $2.49 \mathrm{~m}$ (Bazzoffi, original data).

${ }^{3}$ Since the mid-60's controls have been applied nationwide under what is known as denominazione di origine controllata (denomination of controlled origin) or, by the initials, as DOC. The DOC label, indicates that the wine is produced in a precise area in accordance with specific production procedures that establish the grapes to be used, that is to say, what vines and in what percentage. There are now hundreds of DOC appellations, all delimited geographically. Wines from 24 zones have been further distinguished as DOCG, the G for guaranteed authenticity of wines of particular esteem. For the DOCG wines, the procedures are even stricter and the controls more severe.

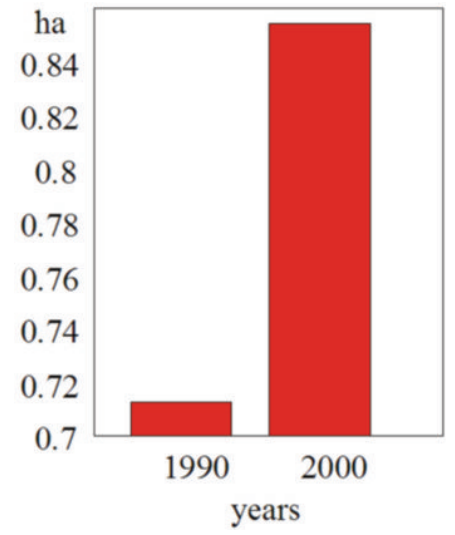

Figure 5. Change in the mean size of vineyards in Italy during the period 1990-2000).

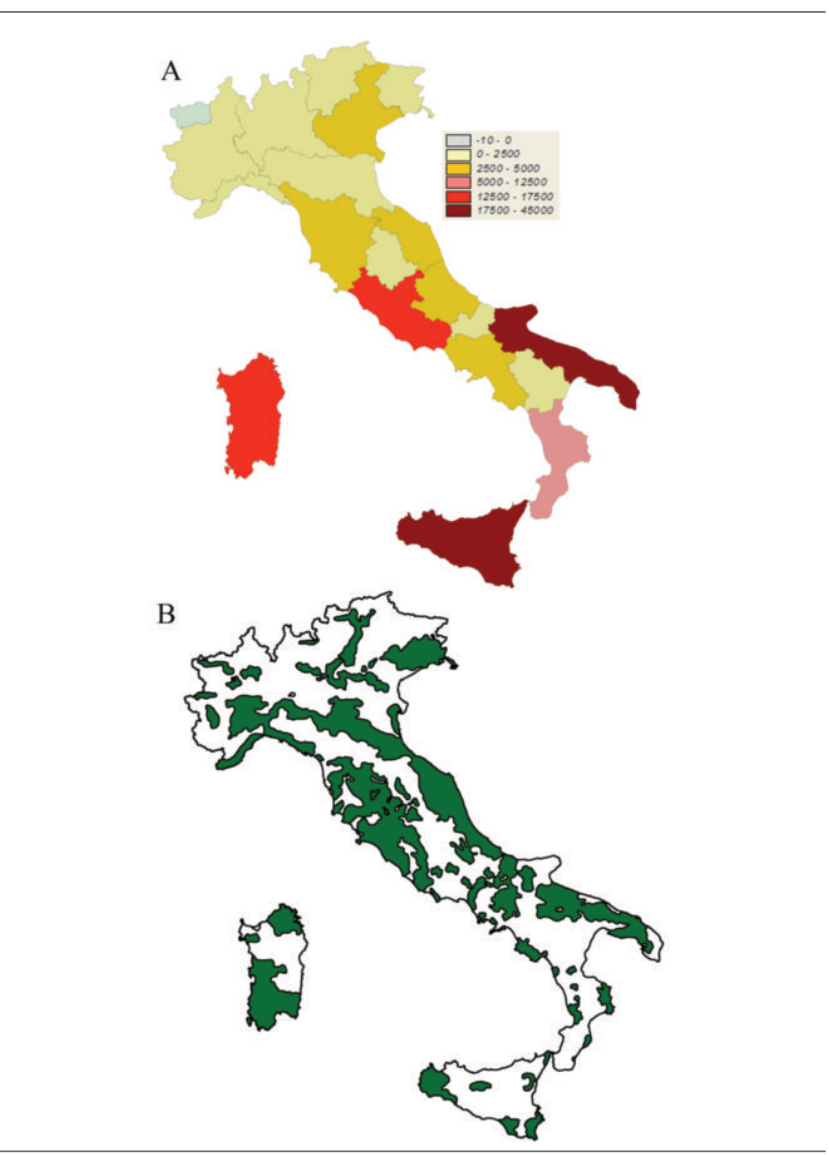

Figure 6. A) increase of vineyard area (ha) by regions between 1990-2002; B) DOC+DOCG wine production areas.

Table 1. Descriptive statistics of excavation and accumulation zone values for the sampled points (distance $2 \mathrm{~m}$ ) obtained from the GRIDs of altimetric differences in the 9 vineyards.

\begin{tabular}{|c|c|c|c|c|c|c|c|c|c|c|}
\hline & Vineyard 1 & Vineyard 2 & Vineyard 3 & Vineyard 4 & Vineyard 5 & Vineyard 6 & Vineyard 7 & Vineyard 8 & Vineyard 9 & 9 All vineyards \\
\hline Area ha & 0.07 & 0.15 & 4.13 & 0.92 & 1.58 & 4.23 & 11.20 & 3.07 & 2.93 & 28.27 \\
\hline No. of survey points & 171 & 368 & 10,317 & 2307 & 3941 & 10,582 & 27,996 & 7663 & 7331 & 70,676 \\
\hline $\begin{array}{l}\text { Excavation / accumulation } \\
\text { zone balance* }(\mathrm{m})\end{array}$ & +3.46 & +2.00 & +0.09 & +0.20 & -1.43 & +6.14 & +2.66 & +1.20 & +4.07 & +2.49 \\
\hline Maximum excavation & 1.38 & 0.28 & 2.46 & 4.22 & 5.35 & 3.05 & 18.93 & 4.72 & 2.86 & 18.93 \\
\hline Maximum accumulation zone $\mathrm{m}$ & 5.36 & 3.35 & 5.35 & 3.58 & 1.92 & 12.16 & 15.62 & 9.95 & 11.05 & 15.62 \\
\hline Deviation standard mean & 1.06 & 0.61 & 1.09 & 1.77 & 1.84 & 3.38 & 7.13 & 2.26 & 1.62 & 5.24 \\
\hline
\end{tabular}

*Positive balance values (i.e. the mean values of excavation and accumulation zones) indicate that there is a prevalence of accumulation zones, while negative values indicate that excavation is prevalent. 
The rise in surface confirms the observations made at Pietrafitta (San Gimignano, Tuscany), using the same survey technique (Bazzoffi et al., 2006). This phenomenon is explained by the fact that in the accumulation areas, the terrain has a lower volumic mass (density) than the soil before cut and occupies therefore a greater volume. Besides the balance between cut and fill it is important to consider the maximum values of digging and filling materials reached during levelling operations. These values enable us to assess the extent to which levelling has changed the landscape.
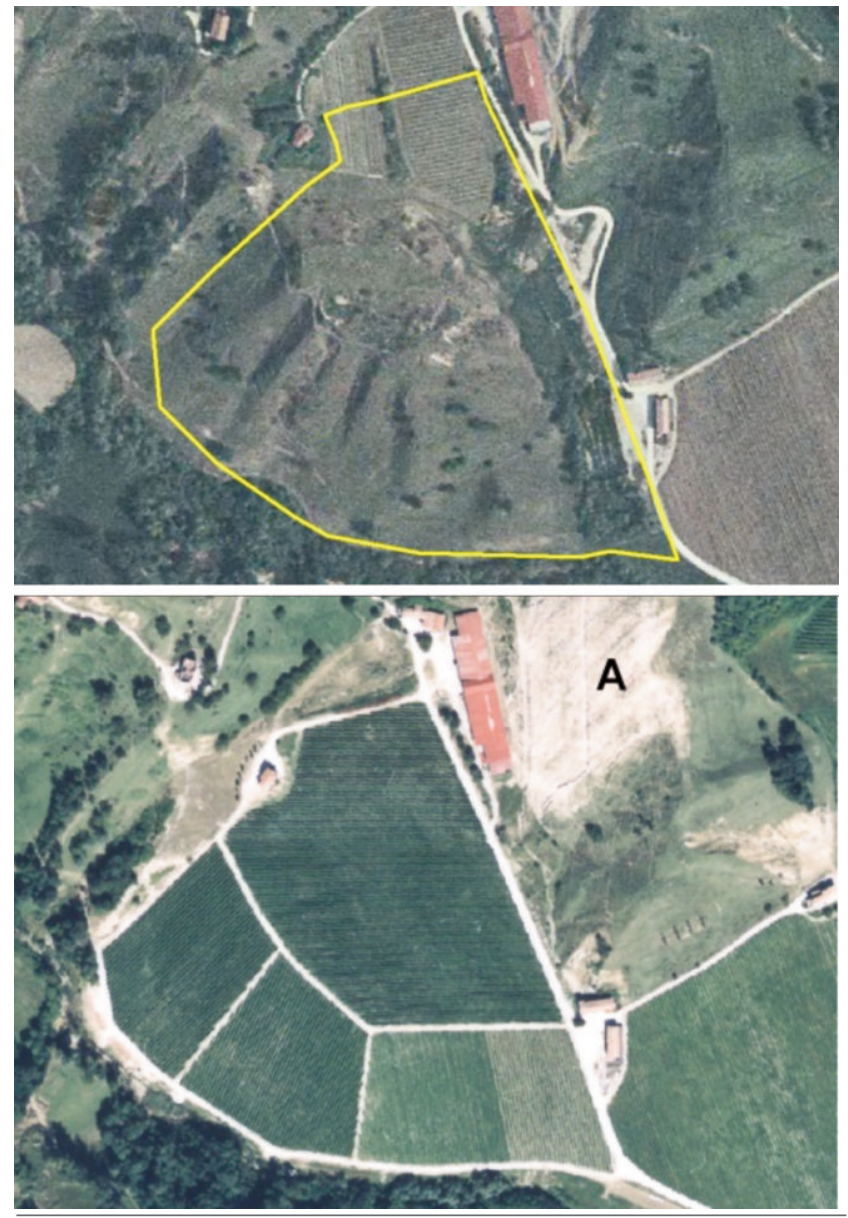

Figure 7 . The area of vineyard no. 7 before and after soil levelling $(A=$ material extraction pit for accumulation zone).

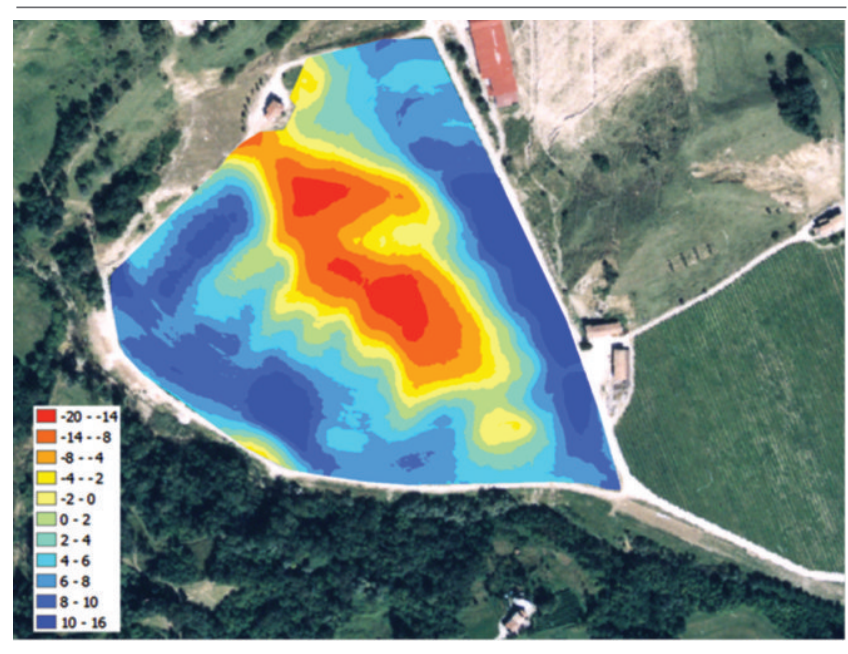

Figure 8. Vineyard no. 7. Thickness (m) of soil moved. Excavations (in red) and accumulation zones (in blue).
Table 1 shows how in vineyard 7 (Figures 7 and 8) there are areas where excavations have reached maximum values of $18.9 \mathrm{~m}$; while in accumulation zones, soil accumulation reached thicknesses of 15.6 metres. The values were high also in the other vineyards. The study emphasized, through a quantitative geomorphic analysis, that levelling has a negative impact on the landscape.

\section{Study site - Emilia Romagna}

Various studies were conducted on the erosion and the production characteristics of a peach orchard and a vineyard in a low hilly area in the municipality of Cesena (Emilia Romagna) in the basin of the Pisciatello torrent. (Bazzoffi et al., 1989; Bazzoffi and Chisci, 1999).

In summer of 1987, on a hill slope characterized by two areas with modest morphological differences ( $L$ and $\mathrm{R}$ in Figure 9; Table 2), the terrain was levelled with total excavation by a rip-plough to a depth of $1.20 \mathrm{~m}$, as preparation for planting of a peach orchard.

The main characteristics of the soil are illustrated in Table 3 (Filippi et al., 1980). Figure 10 shows the thickness of excavation and accumulation zones for the two areas. Table 4 shows statistics regarding the values for excavation and accumulation zones and the mean loss or accumulation of soil in $\mathrm{Mg}_{\mathrm{ha}} \mathrm{h}^{-1}$.

In this area the volumes of soil moved are well below those observed in the Veneto vineyards. However, as described below, soil movements have contributed to the increase in soil erosion.

\section{Study site - Toscana}

The same diachronic analysis of thickness models before and after land levelling was carried out on sandy loam soils in the basin of the Vergaia torrent at Pietrafitta (San Gimignano, Siena). Following levelling, a Merlot vineyard was planted along the maximum slope gradient

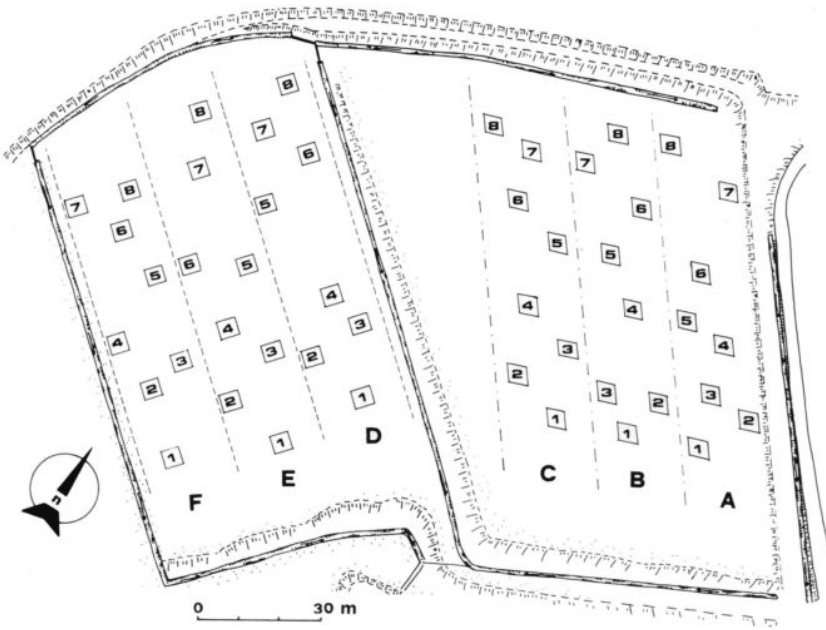

Figure 9. The hill slope under study in Cesena, divided into two areas $L$ (on the left) and $R$ (on the right).

Table 2. Morphometric characteristics of the plots in the two areas. Plot Length (m) Width (m) Area $\left(\mathrm{m}^{2}\right)$ Gradient (\%)

\begin{tabular}{lllll} 
A & 110.0 & 22.5 & 2.475 & 21.5 \\
B & 111.0 & 22.5 & 2.497 & 21.9 \\
\hline C & 111.5 & 22.5 & 2.509 & 22.0 \\
D & 111.0 & 22.5 & 2.498 & 24.0 \\
\hline E & 110.5 & 22.5 & 2.486 & 24.4 \\
F & 106.0 & 22.5 & 2.385 & 24.2 \\
\hline
\end{tabular}


of the hill ( Bazzoffi et al., 2007).

The soil characteristics are illustrated in Table 5. Figure 11 and Table 8 show that also in this area the thicknesses of excavations and accumulation zones were between 0.95 and $1.44 \mathrm{~m}$ with maximum values of around 4-5 m.

\section{Water erosion of soil following levelling}

The levelling of soil almost always determines a pronounced acceleration of water erosion and it is easy to observe incisions on the reshaped surfaces: rills, tunnel erosion (Figures 2 and 3) and gullies (Figure 1d) .

In the areas studied at Cesena, immediately after levelling, six heavy rainfall events occurred between July and September 1987 (for a total of $130 \mathrm{~mm}$. and erosivity of $952.44 \mathrm{MJ} \mathrm{mm} \mathrm{ha}{ }^{-1} \mathrm{~h}^{-1}$ ) causing widespread erosion. The quantity of eroded soil was measured with a pin profiler through reconstruction of the geometry of the rills (Bazzoffi et al., 1989; Bazzoffi and Chisci, 1999). In the case study conducted in Tuscany (Pietrafitta vineyard at San Gimignano, Siena) between August and September (following levelling), 16 highly intensive events occurred for a total of $156 \mathrm{~mm}$ of rainfall and an overall erosivity of 1041.22 $\mathrm{MJ} \mathrm{mm} \mathrm{ha}^{-1}$ which, again in this case, caused widespread erosion with sedimentation of large amounts of earth material on the
Volterra state road (causing a temporary road block).

Table 7 illustrates the values of soil erosion caused by the formation of rills; without considering interrill erosion (Bazzoffi et al., 2007). It appears evident that soil erosion by water after land levelling was extremely intense, both at Cesena and Pietrafitta. In all areas erosion exceeded at least $180 \mathrm{Mg} \mathrm{ha}^{-1}$. These values are far from the tolerance level of $11.2 \mathrm{Mg} \mathrm{ha}^{-1}$ year. Moreover, we have to consider that soil erosion measured by pin profiler relates only to rill erosion. If the values of soil loss by sheet erosion had been added, the values in Table 7 would have been more impressive. It is obvious that in the Cesena and San Gimignano study areas the removal of soil following levelling of the land was absolutely inadmissible and, on account of their gravity, could be classified as catastrophic (Zachar, 1982).

\section{Impact of levelling on vegetative state and production}

In the Cesena study area, the diameter of peach trees trunks nine years after planting was considered in relation to the thickness of excavation and accumulation zones following levelling of the hill slope.

Analysis of the variance conducted for this study (Bazzoffi, original data) shows a significant regression. The coefficient of determination $\mathrm{R}^{2}$ was very low since other sources of variation were involved; first and

Table 3. Main characteristics of the first $40 \mathrm{~cm}$ of soil after levelling and percentage of area occupied by the different soils in the plots (Cesena). Letters A - F indicate the experimental plots in Figure 9.

\begin{tabular}{|c|c|c|c|c|c|c|c|c|c|c|}
\hline \multirow[t]{2}{*}{ Soils } & \multirow{2}{*}{$\begin{array}{c}\text { Horizon A } \\
\text { thickness (m) }\end{array}$} & \multirow{2}{*}{$\begin{array}{l}\text { Sand } \\
(\%)\end{array}$} & \multirow{2}{*}{$\begin{array}{l}\text { Silt } \\
(\%)\end{array}$} & \multirow{2}{*}{$\begin{array}{l}\text { Clay } \\
(\%)\end{array}$} & \multicolumn{6}{|c|}{ Percentage of area occupied by different soils in the plots } \\
\hline & & & & & A & B & $\mathrm{C}$ & D & $\mathbf{E}$ & F \\
\hline Typic udorthents (a) & 0.70 & 56.2 & 37.7 & 7.1 & 65 & 42 & 7 & 13 & 13 & 23 \\
\hline Typic hapludalfs & 0.90 & 10.8 & 48.1 & 41.1 & 0.0 & 13 & 86 & 30 & 38 & 51 \\
\hline Typic udorthents (b) & 0.85 & 28.7 & 47.8 & 23.5 & 35 & 45 & 7 & 58 & 48 & 26 \\
\hline
\end{tabular}

Typic udorthents (a) and (b) differ in the size distribution of primary particles.

Table 4. Statistics showing thickness of excavation and accumulation zones in the two experimental areas (Cesena).

\begin{tabular}{|c|c|c|c|c|}
\hline & \multicolumn{2}{|c|}{ Cesena (area L) } & \multicolumn{2}{|c|}{ Cesena (area R) } \\
\hline & Accumulation areas & Excavation areas & Accumulation areas & Excavation areas \\
\hline Soil volume $\left(\mathrm{m}^{3}\right)$ & 2141 & 2204 & 1613 & 5899 \\
\hline $\operatorname{Area}\left(\mathrm{m}^{2}\right)$ & 2299 & 3276 & 1517 & 3873 \\
\hline Mean thickness (m) & 1.02 & 0.77 & 0.47 & 0.54 \\
\hline Maximum thickness (m) & 2.60 & 1.90 & 1.40 & 1.30 \\
\hline Minimum thickness (m) & 0,10 & 0.10 & 0.10 & 0.10 \\
\hline C.L. $\pm 95 \%(\mathrm{~m})$ & 0.29 & 0.13 & 0.15 & 0.08 \\
\hline Mean loss or accumulation of soil $\left(\mathrm{Mg} \mathrm{ha}^{-1}\right)$ & 16.32 & 12.32 & 7.52 & 8.64 \\
\hline Total area $\left(\mathrm{m}^{2}\right)$ & \multicolumn{2}{|c|}{10828.9} & \multicolumn{2}{|c|}{7682.5} \\
\hline
\end{tabular}

Table 5. Characteristics of the first $40 \mathrm{~cm}$ of soil at Pietrafitta (San Gimignano, Siena).

\begin{tabular}{|c|c|c|c|c|c|}
\hline Soils & $\begin{array}{l}\text { Thickness } \\
\text { horizon A } \\
\text { m }\end{array}$ & $\begin{array}{l}\text { Sand } \\
(\%)\end{array}$ & $\begin{array}{l}\text { Silt } \\
(\%)\end{array}$ & $\begin{array}{l}\text { Clay } \\
(\%)\end{array}$ & $\begin{array}{c}\text { Percentage of area } \\
\text { occupied by different soils }\end{array}$ \\
\hline $\begin{array}{l}\text { Typic Xerochrepts } \\
\text { Sandy loam, Strada series }\end{array}$ & 0.30 & 50.8 & 35.6 & 13.6 & 53 \\
\hline $\begin{array}{l}\text { Typic Xerochrepts } \\
\text { Silty loam phase }\end{array}$ & 0.25 & 41.6 & 37.3 & 21.1 & 27 \\
\hline $\begin{array}{l}\text { Typic Xerochrepts } \\
\text { Eroded phase of Strada series }\end{array}$ & 0.20 & 39.3 & 45.7 & 15.0 & 20 \\
\hline $\begin{array}{l}\text { Typic Xeropsamments } \\
\text { Eroded phase of Cusona series }\end{array}$ & 0.30 & 70.6 & 19.8 & 9.6 & 0.3 \\
\hline
\end{tabular}


foremost, the soil moisture gradient, which appeared to increase from the top to bottom of the hill, fertilization and pruning. This therefore shows that the growth of plants is penalized in areas where the soil profile has been truncated. In the Pietrafitta (San Gimignano, Siena) vineyard, a survey was made three years after excavation of the main production and qualitative/quantitative parameters of the vines.

The analysis in Table 9 shows that in the areas where soil was removed, with emergence of the deep horizon (horizon $\mathrm{C}$ ), the vines suffered due to a reduction in vegetative and bunch growth; while in the areas where there was an accumulation of soil, the vines suffered a lower synthesis of anthocyanin and polyphenol content together with a lower sugar level (Bazzoffi et al., 2007).

Regression 1 (Table 9) shows that SPAD values (estimate of chlorophyll content) are strongly related to the thickness of excavation and accumulation zones. The greater the thickness of accumulated soil, the higher the SPAD value, conversely, the greater the thickness of soil removed, the lower the SPAD value.

At Pietrafitta, like Cesena, the effect of height along the hill slope favours the vines from hilltop down towards the valley; probably due to the increasing water gradient.

Evidence of the decrease in land suitability and decay in soil quality can often be observed directly in the field. Figure 12 shows a vineyard affected by degradation and productivity loss at Gambassi (province of Florence), over a large area due to land levelling. On this land soil scraping by bulldozer determined the outcrop of clayey subsoil (greyish) of undesirable quality.

\section{Authorization to level land: professional responsibility and public control on the movement of earth for agri- cultural purposes}

Italy has few agricultural terrains and many of these have been consumed by the expansion of towns and infrastructures; a large number of those that remain are in hilly areas. There is a strong risk of erosion

Table 6. Statistics showing thickness of excavation and accumulation zones at Pietrafitta (San Gimignano, Siena).

\begin{tabular}{|c|c|c|}
\hline & \multicolumn{2}{|c|}{ Pietrafitta } \\
\hline & $\begin{array}{l}\text { Accumulation } \\
\text { areas }\end{array}$ & $\begin{array}{l}\text { Excavation } \\
\text { areas }\end{array}$ \\
\hline Soil volumes $\left(\mathrm{m}^{3}\right)$ & 27558.6 & 18263.9 \\
\hline Area $\left(m^{2}\right)$ & 31418.2 & 14198.3 \\
\hline Mean thickness (m) & 0.95 & 1.44 \\
\hline Maximum thickness (m) & 3.65 & 5.72 \\
\hline Minimum thickness (m) & 0.18 & 0.006 \\
\hline C.L. $\pm 95 \%(\mathrm{~m})$ & 0.055 & 0.102 \\
\hline Mean soil loss or accumulation $\left(\mathrm{Mg} \mathrm{ha}^{-1}\right)$ & -1) 15,200 & \\
\hline
\end{tabular}

Table 7. Measurement of channelled erosion following levelling of hill slopes at Cesena and Pietrafitta.

\begin{tabular}{lcc} 
Area & $\begin{array}{c}\text { Volume of rills } \\
\left(\mathrm{m}^{3} \mathrm{ha}^{-1}\right) \\
\pm \text { conf. } 95 \%\end{array}$ & $\begin{array}{c}\text { Total channelled erosion } \\
\left(\mathrm{Mg} \mathrm{ha}^{-1}\right) \\
\pm \text { conf. } 95 \%\end{array}$ \\
Pietrafitta & $115 \pm 26$ & $184 \pm 41$ \\
Cesena plot A & $336 \pm 68$ & $538 \pm 108$ \\
\hline Cesena plot B & $280 \pm 96$ & $448 \pm 153$ \\
Cesena plot C & $125 \pm 24$ & $200 \pm 38$ \\
\hline Cesena plot D & $238 \pm 43$ & $381 \pm 69$ \\
Cesena plot E & $164 \pm 35$ & $262 \pm 56$ \\
\hline Cesena plot F & $194 \pm 47$ & $310 \pm 75$
\end{tabular}
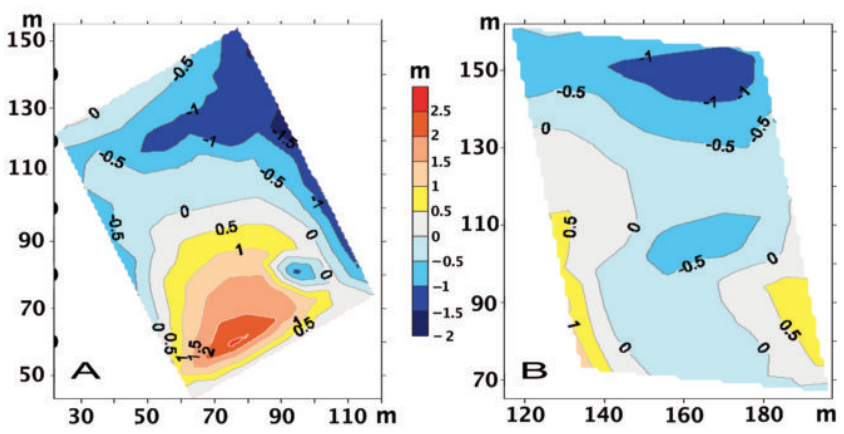

Figure 10. Thickness of excavation and accumulation zones in the two experimental areas ( $L$, on the left and $R$, on the right) in the municipality of Cesena). Grey and red indicate accumulation areas; light blue to blue indicate excavation areas.
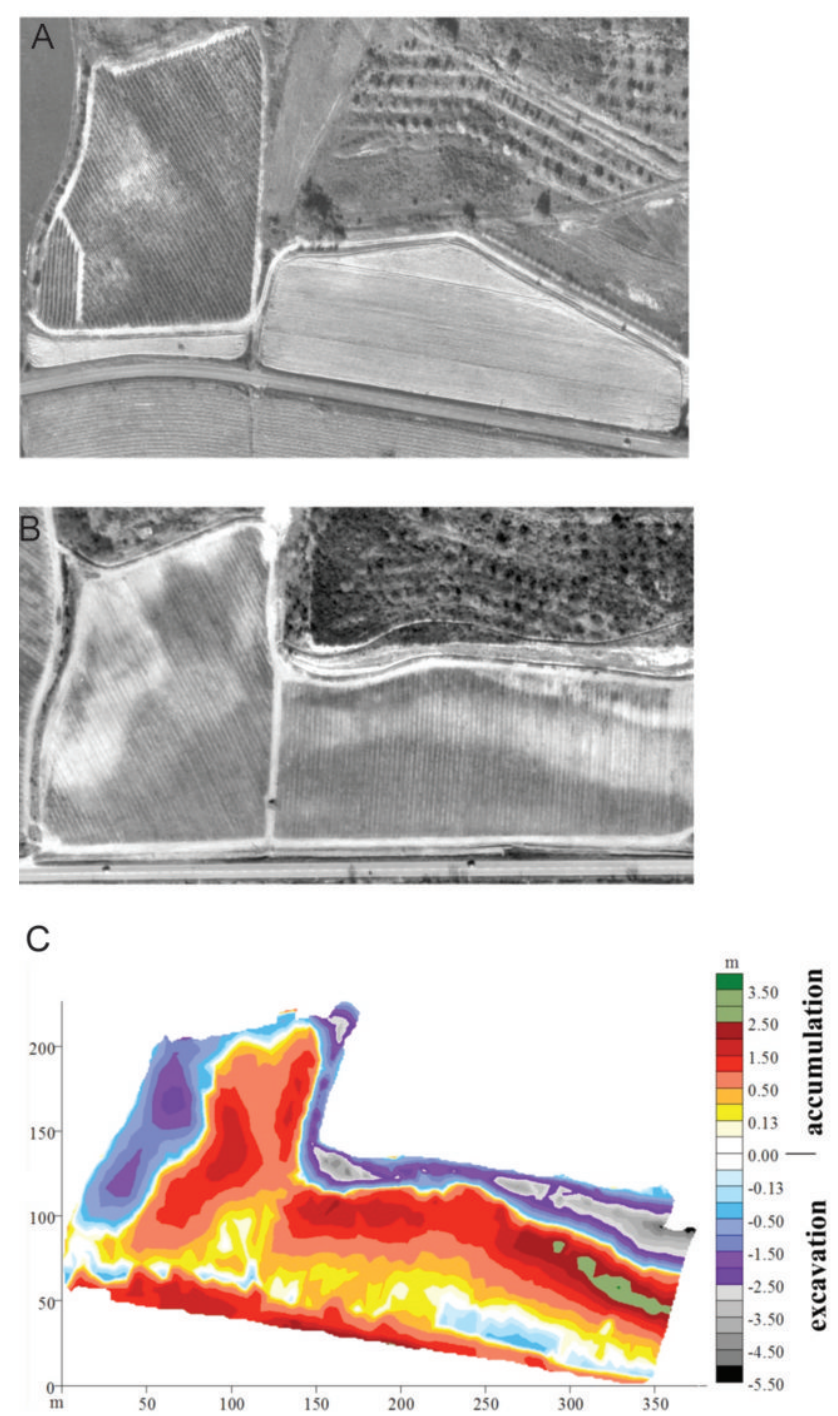

Figure 11. Area studied at Pietrafitta (San Gimignano, Siena). A) before levelling; B) after levelling; C) subtraction between Digital Terrain Model (DTM). Yellow to green colours indicate accumulation areas, light blue to black indicate excavation areas. 
and hydrogeologic imbalance, as shown by the several disastrous events that take place particularly on the occurrence of extreme rainfall events. With regard to the movement of soil in preparation for planting specialized cultures, there is no general consistent regulation calling for the necessity to preserve the soil resource.

While the legislator warns of the necessity to prevent seismic risk and, more in general, to control building activities, prevention of hydrogeologic risk is entrusted almost entirely to the hydrogeological constrain which is rather bland where risks connected to land levelling are concerned: "Any human activity and action which directly or indirectly disturbs the hydrogeologic balance which the hydrogeologic constraint aims to safeguard, shall be reported in advance to the Forestry Commission who will give their formal consent with the sole exception of the movement of earth, for which authorization shall be granted on the basis of the tacit consent principle on termination of the prescribed term." [CDS, section V, 30.09.1983, n. 408].

On the other hand, urban planning is called on by various regional laws, although not by all, to guarantee the sustainable use of essential resources, which obviously includes soil. But agriculture eludes this discipline.

"Urban planning concerns regulating the use of the territory (D.P.R. 24-7-1977, no. 616, art. 80) and not only the particular use of it made by building activities: this therefore includes all cognitive, normative and managerial aspects for the safeguard and transformation of land as well as protection of the environment. It follows that while work authorization for land transformation is not normally required, an urban-plan-

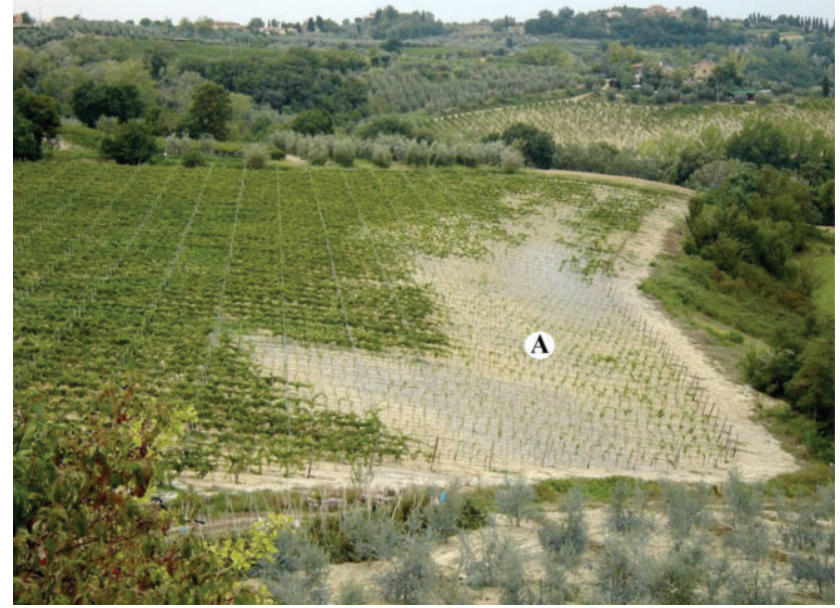

Figure 12. Vineyard affected by degradation and productivity loss over a large area (zone A) due to land levelling. Soil scraping determined the outcrop of clayey subsoil (grayish) of undesirable quality (Gambassi, Tuscany).

Table 8. Measurement of channelled erosion following levelling of hill slopes at Cesena and Pietrafitta.

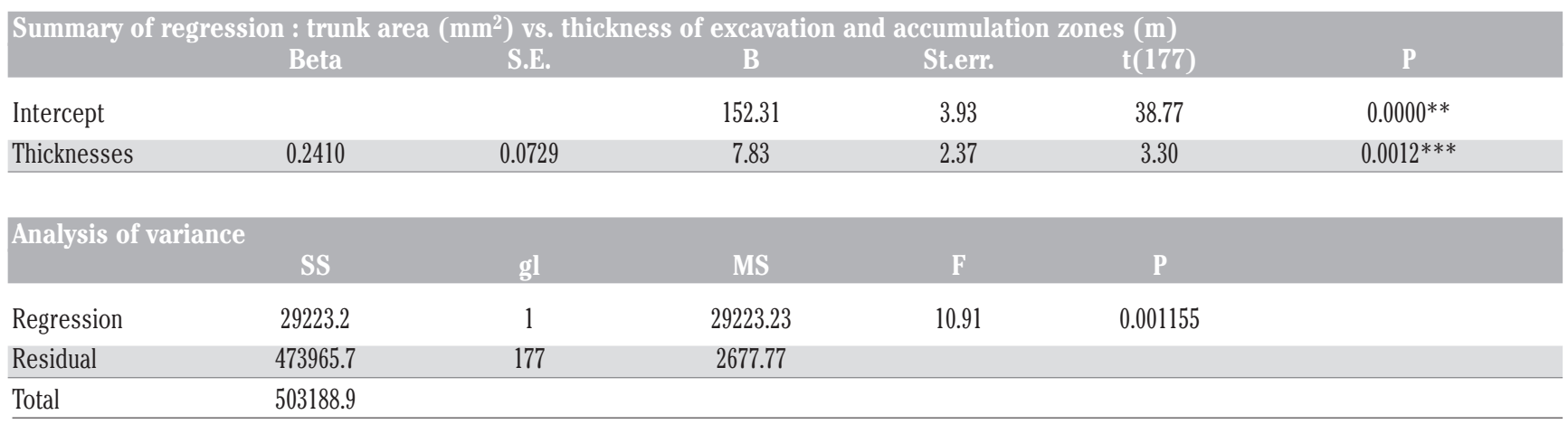

Table 9. Stepwise regression analyses for vine and grape parameters (Pietrafitta vineyard).

\begin{tabular}{|c|c|c|c|c|c|c|c|c|c|}
\hline Regression & Parameter & Intercept & $\begin{array}{l}\text { Coefficient } \\
\text { Excavations / } \\
\text { accumulation zones }\end{array}$ & $\begin{array}{l}\text { s of regres } \\
\text { Height } \\
\text { (m) }\end{array}$ & $\begin{array}{l}\text { ssion and p } \\
\text { SPAD }\end{array}$ & $\begin{array}{l}\text { ameters } \\
\text { F regression }\end{array}$ & P regression & $\mathbf{R}$ & $\mathbf{R}^{2}$ \\
\hline 1 & SPAD & $\begin{array}{c}32.85 \\
(0.000 * *)\end{array}$ & $\begin{array}{c}6.34 \\
\left(0.008^{* *}\right)\end{array}$ & $\begin{array}{c}0.01 \\
(0.065 \mathrm{~ns})\end{array}$ & $\begin{array}{c}8177.8 \\
-\end{array}$ & $(2-15985)$ & $<0.000^{* *}$ & 0.71 & 0.51 \\
\hline 2 & $\begin{array}{l}\text { Prod. bunches } \\
\text { (g/plant) }\end{array}$ & $\begin{array}{c}-440.5 \\
\left(0.048^{* *}\right)\end{array}$ & $\begin{array}{c}-18.7 \\
(0.185 \mathrm{~ns})\end{array}$ & $\begin{array}{c}2.68 \\
(0.110 \mathrm{~ns})\end{array}$ & $\begin{array}{c}7.26 \\
\left(0.000^{* * *}\right)\end{array}$ & $\begin{array}{c}20.0 \\
(3-29)\end{array}$ & $<0.000^{* *}$ & 0.82 & 0.64 \\
\hline 3 & $\begin{array}{l}\text { Anthocyanins } \\
\text { mg/50 berries }\end{array}$ & $\begin{array}{c}118.4 \\
\left(0.003^{* *}\right)\end{array}$ & $\begin{array}{c}-10.64 \\
\left(0.000^{* *}\right)\end{array}$ & $\begin{array}{c}-0.68 \\
\left(0.022^{* *}\right)\end{array}$ & $\begin{array}{c}0.28 \\
(0.129 \mathrm{~ns})\end{array}$ & $\begin{array}{c}6.9 \\
(3-29)\end{array}$ & $<0.002 * *$ & 0.65 & 0.42 \\
\hline 4 & $\begin{array}{l}\text { Polyphenols } \\
\text { mg/50 berries }\end{array}$ & $\begin{array}{c}222.5 \\
\left(0.006^{* *}\right)\end{array}$ & $\begin{array}{c}-16.62 \\
\left(0.002^{* *}\right)\end{array}$ & $\begin{array}{c}-0.81 \\
(0.167 \mathrm{~ns})\end{array}$ & $\begin{array}{c}-0.69 \\
(0.067 \mathrm{~ns})\end{array}$ & $\begin{array}{c}9.2 \\
(3-29)\end{array}$ & $<0.002^{* *}$ & 0.70 & 0.49 \\
\hline 5 & $\begin{array}{l}\text { Weight of } 50 \\
\text { berries }\end{array}$ & $\begin{array}{c}41.47 \\
\left(0.002^{* *}\right)\end{array}$ & $\begin{array}{c}-8.07 \\
(0.062 \mathrm{~ns})\end{array}$ & Excluded & $\begin{array}{c}1.17 \\
\left(0.001^{* * *}\right)\end{array}$ & $\begin{array}{c}6.4 \\
(3-29)\end{array}$ & $<0.005^{* *}$ & 0.55 & 0.30 \\
\hline 6 & $\begin{array}{l}\text { Sugars } \\
\text { Brix }\end{array}$ & $\begin{array}{c}31.64 \\
\left(0.000^{* *}\right)\end{array}$ & $\begin{array}{c}-0.81 \\
\left(0.003^{* *}\right)\end{array}$ & $\begin{array}{c}-0.07 \\
(0.095 \mathrm{~ns})\end{array}$ & $\begin{array}{c}-0.04 \\
(0.134 \mathrm{~ns})\end{array}$ & $\begin{array}{c}4.9 \\
(3-29)\end{array}$ & $<0.007^{* *}$ & 0.58 & 0.34 \\
\hline 7 & $\begin{array}{c}\text { Acidity } \\
\text { (tartaric) }\end{array}$ & $\begin{array}{c}-13.01 \\
(0.66 \mathrm{~ns})\end{array}$ & $\begin{array}{c}0.64 \\
(0.66 \mathrm{~ns}) \\
\text { Forced }\end{array}$ & $\begin{array}{l}0.15 \\
(0.51 \mathrm{~ns}) \\
\text { Forced }\end{array}$ & $\begin{array}{c}0.02 \\
(0.75 \mathrm{~ns}) \\
\text { Forced }\end{array}$ & $\begin{array}{c}0.1 \\
(3-29)\end{array}$ & $\begin{array}{c}<0.901 \\
n s\end{array}$ & 0.35 & 0.12 \\
\hline
\end{tabular}

SPAD, chlorophyll content value; ns, not significant. 
ning authorization is however required when the morphology of the land is altered following important excavation works andor levelling etc. for other than agricultural purposes including tourist or sport activities." [Criminal Court of Cassation, section III, 13.11.2002, no. 38055 and Criminal Court of Cassation, section. III, 04.04.2008, n. 14243].

Our regulations therefore have a grey area, in which even the massive scale levelling and movement of soil in an agricultural environment is not subject to any control.

This shortcoming has recently been acknowledged by Administrative law: The Regional Administrative Court (TAR) of Lombardy (MI), with sentence no. 2997 of 19.12 .2006 clarified the necessity to submit a Statement of Commencement of Activity (DIA) for levelling operations on agricultural land with accumulation zones entailing transformation of the territory. This sentence is based on the current Building Consolidation Act, and, more specifically, on the provision (art. 22, first sub-paragraph, D.P.R. 6 June 2001 no. 380) which calls for the submission of a DIA, also in the case of land setting works involving besides mere cultivation, also transformation of the territory. The aim of Art. 22 is to avoid important interventions evading inspection by the Authority responsible for controlling the territory. Therefore, the sentence continues, "any intervention which ... does not consist in merely filling holes, but in a significant accumulation of hundreds of cubic metres, cannot be considered irrelevant."

Having said this, it is more than licit to doubt that a DIA is a suitable instrument for guaranteeing correct interventions on the land. In fact:

1. The person signing the DIA is not required to have any specific technical competence for assessing the environmental impact of levelling;

2. The DIA need not be accompanied by an exhaustive geo-pedologic study of the site, which also includes an assessment of damages to the soil resource in terms of truncation and/or burial of the profile and an estimate of erosion;

3. The DIA is not required to asseverate that soil losses remain below sustainable values;

4. No control of merit is envisaged on the DIA, even by random sampling, as it ususally occurs in the case of anti-seismic projects and modifications;

5. No professional figure is required to assume responsibility for the correct execution of soil levelling works, nor is a public control envisaged to control their correct execution;

6. Authorization is considered as granted at the end of the implicit consent period.

For all this, the deficient grey area in the regulations remains, as does the risk (indeed, the certainty) that important interventions continue to be undertaken outside the bounds of all technical-planning responsibility and with no public control. This latter is absolutely necessary and legitimated by the fact that preserving the hydro-geologic balance as well as the production capacity of its agricultural land (land capability) is a public interest matter, especially where there are top quality productions at stake, which represent the heritage and identity of entire regions (just think, for example, of Italy's finest wines).

On the other hand, it is quite illogical that the control mechanisms for irrelevant building works (e.g. light restructuring of private houses) should be stricter than those for transforming and potentially putting an entire hill at risk.

It is therefore essential to bridge this lacuna legis and subject soil movement for agricultural purposes to the logical responsibility of a professional figure, on one side, and to control and public authorization on the other.

To this end, it is suggested that the following regulatory key elements be introduced into current legislation, either as a single provision or as integrations and amendments to existing procedures, as for example the DPR 380 previously referred to:

1. It is necessary to establish the principle that soil movement should obtain a specific qualifying document (building license, authorization, etc.).

2. The project for soil movement should be submitted by a qualified professional figure and should contain:

A. The name of the works manager and the firm carrying out the works;

B. A plano-altimetric survey of the land prior to levelling;

C. A plano-altimetric representation of the land after levelling;

D. A map of excavation and accumulation zone thickness, in the form of equidistant decimetric contour lines (positive isopachs for accumulation zones, and negative for excavations);

E. An indication of the direction of any deep ploughing,

F. A project, with relevant hydraulic calculations, of the primary and secondary drainage network, roads, ditches, etc;

G. A project for consolidation works in the accumulation of earth material;

H. Geo-pedological report showing safeguarding of soil resource and maintenance of erosion within tolerable limits both during and after levelling;

I. A detailed pedological report (map of soils and pedological report) on the situation prior and subsequent to levelling, with a judgement on feasibility in order to guarantee, by means of appropriate tests on sample areas, that areas with poorer physical, chemical and water deficiency characteristics for plants do not emerge on the levelled surface, also because of the increased risk of droughty years caused by the current changes in climate;

J. Detailed geological report on feasibility of the intervention insofar as regards the changes induced on surface and deep hydrology, on the stability of hill slopes and on long distance effects (where necessary, depending on the value of the goods down the land to be levelled exposed to the harmful effects of sediments delivered to the river network);

K. Recovery and protection plan giving the following indications: 1) The area adjacent to the levelled area, for the accumulation of earth material obtained from fertile surface horizons and method of their redistribution over the levelled land, 2) measures to be adopted to reduce erosion to the minimum;

L. owner commitment to implement erosion control measures.

3) The project should be controlled and authorized by the Municipal authorities, who will ensure the necessary competence in terms of personnel or with the collaboration of specialized professional figures to be integrated in the building committee or in a specific committee for territorial structuring.

4) Alternatively, the control may also be undertaken by the authority competent for public funding, provided it has or acquires the necessary technical expertise.

5) The procedure ends with the issue of a document qualifying the activity, which shall contain the name of the expert who will manage the works and will asseverate the correct execution at their completion.

6) The qualifying document and the technical asseveration are indispensable for obtaining public funds.

7) Any departures from the above procedure in favour of the implicit consent principle are inacceptable, with the exception of works carried out by the civil defence authorities.

\section{Discussion and Conclusion}

The results of research conducted in Italy show that the levelling of land seriously disturbs the soil resource, determining impressive truncations and burial of soil profile. This leads to considerable limitation in use, even towards desertification. By way of example, we cite the 
case of a vineyard in Veneto where a hill was decapitated to plant a vineyard, with excavation thickness touching $19 \mathrm{~m}$ and accumulation zone thickness of $16 \mathrm{~m}$. From information obtained in the area, we learned that one of the reasons for these massive movements of earth was the method adopted by the owners of the earth-moving company to pay for labour. In other words, workers' pay was geared to the volumes of earth moved, without respecting the environment, due to the lack of a specific ruling on the subject. In general, after levelling, erosion rates may exceed $300 \mathrm{Mg} \mathrm{ha}^{-1}$ on hill slopes where there is no vegetative protection and are exposed to rainfalls; these are classified as catastrophic erosion by Zachar (1982) and are far from the tolerable erosion limits of 6-11.2 $\mathrm{Mg} \mathrm{ha}^{-1}$ year-1, currently accepted internationally.

By applying the results obtained to Italy, the conclusions reached are somewhat worrying. Statistics show that in the 80's, the surface area levelled or risking further levelling on replanting vineyards at the end of their cultural cycle, was about 1260 hectares. On part of this area, which in all likelihood has already been levelled, viticulture has made way for other uses, but the soil may well have suffered permanent damage. Moreover, the increase in the levelled, or reshaped, surface in the re-planting stage, particularly in DOC, DOCG and IGT areas must be added to these 1260 ha. Tests on the vegetational parameters of the Cesena peach orchard and the vineyard in the San Gimignano area show that in the areas where soil was removed, the use of the land is limited, mainly due to water stress following the reduction in the depth explorable by the roots. In order to optimize levelling and preserve fertility and soil type, great attention should be paid to the impact of these operations and implementation of corrective measures based on suitable regulations.

\section{Proposals to update the GAEC Standard}

The proposals to update the Regulation are as follows:

i) Extension of the land levelling under authorization rule to include reshaping for the creation or re-creation of dry stone wall and earth terraces with grassed cliff downhill.

ii) The obligation to submit, during controls on the observance of cross compliance, a DIA (or authorization) where due, on the basis of which it can be inferred that the levelling was undertaken during the efficacy of the cross compliance regime.

iii) For plots of land levelled or reshaped after promulgation of the next decree of compliance, the obligation to submit a geo-pedological report to the cross-compliance controller in order to demonstrate that the levelling was undertaken by following soil conservation criteria; it should bear a firm date and be drawn up by a professional prior to levelling, containing the elements indicated in paragraph Authorization to level land (points A-L).

\section{References}

Bazzoffi P., 2009. Soil erosion tolerance and water runoff control: min- imum environmental standards. Reg. Environ. Change 9:169-179.

Bazzoffi P., Abbattista F., Vanino S., Pellegrini S., 2006. Impact of land levelling for vineyard plantation on soil degradation in Italy. Bollettino della Società Geologica Italiana. Volume speciale, pp. 191-199

Bazzoffi P., Chisci G., 1999. Tecniche di conservazione del suolo in vigneti e pescheti della collina cesenate. Riv. Agron. 3:177-184.

Bazzoffi P., Chisci G., Missere D., 1989. Influenza delle opere di livellamento e scasso sull'erosione del suolo nella collina Cesenate. Riv. Agron. 23:213-221.

Bazzoffi P., Pellegrini S., 1992. Caratteristiche delle piogge influenti sui processi erosivi nel periodo 1964-1990 in un ambiente della valle dell'Era (Toscana). Evoluzione climatica e modelli previsionali. Ann. Ist. Sperim. Studio Difesa Suolo 20:161-182.

Bazzoffi P., Pellegrini S., Storchi P., Bucelli P., Rocchini A., 2007. Impact of land levelling on soil degradation, vineyard health and grape quality. pp 346-357 in Proc. 11th GESCO International Symp., Porec, Croatia.

EEA, 1998. Europe's Environment: The Second Assessment. Office for Official Publications of the European Communities, Luxembourg. Available from: http://themes.eea.eu.int/

Filippi N., Preti D., Missere D., Chisci G., Angelelli A., 1980. I suoli della collina cesenate. Regione Emilia-Romagna Ed., Bologna, Italy.

Grimm M., Jones R.J.A., Montanarella L., 2001. Soil Erosion Risk in Europe. European Soil Bureau, Institute for Environment \& Sustainability, JRC Ispra. Office for Official Publications of the European Communities, Luxembourg.

INEA, 2003. Annuario dell'Agricoltura Italiana. Vol. 56, Edizioni Scientifiche Italiane, Napoli, Italy.

ISTAT, 2001. Censimento Agricoltura 2000. Elenchi regionali on line, tavole 1.3-1.4. Available from: www.census.istat.itlindex_agricoltura.htm.

Kendall H., Pimentel D., 1994. Constraints on the Expansion of the Global Food Supply. Ambio 23:198-205.

Morando A., 2001. Vigna Nuova. Materiali e tecniche per l'impianto del vigneto. Vit.En. Ed., Calosso d'Asti, Asti, Italy.

NRCS-USDA (Natural Resources Conservation Service), 1999. National Soil Survey Handbook-Title 430-VI. Available from: http:/www.statlab.iastate.edu/soils/nssh/

OECD, 2001. Environmental indicators for agriculture. Methods and results, vol 3. OECD Publ., Paris, France.

Panichi M., Corti G., Vieri M., 2006. La gestione dello scheletro nei nuovi schemi sistematori dei vigneti. In: Linee guida per la gestione sostenibile dei vigneti collinari. Autorità di Bacino del Fiume Arno Ed., Firenze, Italy.

Stallard R.F., 1995. Tectonic, Environmental, and Human Aspects of Weathering and Erosion: A Global Review using a Steady-State Perspective. Annu. Rev. Earth Pl. Sci. 23:11-39.

Zachar D., 1982. Soil Erosion. Developments in Soil Science. Elsevier Scientific Publ., Amsterdam, The Netherlands. 